\title{
Efektivitas Pembelajaran Pendidikan Agama Islam (PAI) Dengan Model Discovery Learning Dalam Meningkatkan Motivasi Dan Hasil Belajar Siswa di SMP Negeri I Lawang Wetan Tenti Anggreasi \\ Mahasiswa Program Pasca Sarjana Fakultas Tarbiyah dan Ilmu Keguruan \\ Universitas Islam Negeri Raden Fatah Palembang \\ E-mail: tentianggreasi17@gmail.com
}

\begin{abstract}
Abstrak:
Efektivitas pembelajaran dengan Model discovery learning cara aktif dan menyenangkan, dengan cara ini guru memancing kreatifitas siswa dengan menggunakan media. Tujuan penelitian ini untuk mengetahui efektivitas dengan model Discovery Learning terhadap motivasi dan hasil belajar siswa dan ada tidaknya perbedaan antara motivasi dan hasil belajar siswa setelah diterapkannya model discovery learning dalam pembelajaran Pendidikan Agama Islam di SMP Negeri 1 Lawang Wetan. Penelitian ini menggunakan metode penelitian eksperimen, karena dalam penelitian ini, peneliti membagi objek yang diteliti menjadi dua kelompok yaitu kelompok eksperimen dan kelompok kontrol. Pengumpulan data menggunakan teknik observasi, dokumentasi, angket dan tes. Analisis data dengan menggunakan uji normalitas, uji homogenitas dan uji T. Berdasarkan data motivasi belajar diperoleh nilai rata-rata kelas eksperimen 90.71 sedangkan rata-rata nilai kelas kontrol 84.57. Adapun nilai uji T menunjukkan bahwa nilai $t_{0} 3,856$. Kemudian setelah itu dikonsultasikan dengan $t_{\text {tabel }}$ bahwa pada tarap $5 \% \mathrm{t}_{\text {tabel }}$ atau $t_{t}=2,00$, pada tarap $1 \% \mathrm{t}$ tabel atau $\mathrm{t}_{\mathrm{t}}=2,65$, dengan perincian $2,00<3,856>2,65$. Karena signifikansi $<0,05$ $(0,000<0,05)$. Berdasarkan data hasil belajar diperoleh nilai rata-rata kelas eksperimen eksperimen 82.81 , sedangkan nilai rata-rata kelas kontrol 62.41. berdasarkan uji $\mathrm{T}$ diperoleh kesimpulan bahwa terdapat perbedaan nilai hasil belajar Pendidikan Agama Islam sebelum dan sesudah menggunakan model discovery learning
\end{abstract}

Kata Kunci: Discovery Learning, Motivasi , Hasil Belajar

\begin{abstract}
:
The purpose of this study is to find out the effectiveness of the Discovery Learning model on students' motivation and learning achievement and whether or not there was a significant difference between students'motivation and learning achievement after the implementation of discovery learning model in the learning of Islamic Religion in SMPN 1 Lawang Wetan. This study used experimental research method because the researcher divided the students into two groups, namely the experimental group and the control group. The data were collected through the techniques of observation, documentation, questionnaire and test. Then, the data gained were analyzed using normality test, homogeneity test and T-test. Based on the data of the students' learning motivation, it was found out that the average score of the students in the experimental group was 90.71. While the average score of the students in the control group was 84.57. The T-test value showed that the value was 3.856. Then, it was consulted with t-table that was in the significance degree of $5 \%$ of t-table $=2.00$, and in the significance degree of $1 \%$ of t-table $=2.65$, with details $2.00<3.856>2.65$ because the significance degree was $<0$, $05(0,000<0,05)$. Based on the data of the students' learning achievement, the average score of the students in the experimental group was 82.81. While the average score of the students in the control group was 62.41. Based on the T-test analysis, it was concluded that there were significant differences in the scores of students' learning achievement in the learning of Islamic Religion before and after using the discovery learning model.
\end{abstract}

Keywords: Discovery Learning, Motivation, Learning Achievement 


\section{Pendahuluan}

Discovery learning merupakan suatu rangkaian kegiatan pembelajaran yang melibatkan secara maksimal seluruh kemampuan siswa untuk mencari dan menyelidiki secara sistematis, kritis dan logis sehingga mereka dapat menemukan sendiri pengatahuan, sikap dan keterampilan sebagai wujud adanya perubahan prilaku (Hanafiah, 2014: 77).

Pembelajaran discovery learning adalah suatu model untuk mengembangkan cara siswa belajar aktif dengan menemukan sendiri, menyelidiki sendiri, sehingga hasil yang diperoleh lebih bermakna, tahan lama dan tidak mudah dilupakan siswa (Hosnan, 2015: 282).

Dalam pembelajaran discovery learning siswa didorong untuk menemukan sendiri dan mentransformasikan informasi kompleks, mengecek informasi baru dengan yang sudah ada dalam ingatannya, dan melakukan pengembangan menjadi informasi atau kemampuuanyang sesuai dengan perkembangan zaman.

Untuk menuju ke arah efektivitas dalam mengelola pendidikan, kegiatan belajar mengajar di sekolah idealnya harus mengarah pada kemandirian peserta didik dalam belajar. Menurut teori kontruktivisme, peserta didik harus dapat menemukan sendiri dan mentransformasikan informasi kompleks.

Efektivitas pembelajaran adalah keberhasilan dalam proses dalam proses dan hasil belajar mengajar yang telah direncanakan atau dapat terlaksana dengan baik, guru sebagai pendidik yang mengajar dan murid sebagai subjek yang belajar. Keefektifitas sangat berkaitan dengan proses pencapai hasil tersebut. Maka dari penggunaan metode pembelajaran dikatakan efektif jika dalam proses dan hasil belajar itu sudah mencapai tujuan yang diinginkan dengan cara melihat indikator dari tujuan pembelajaran itu sendiri.Untuk mengembangkan potensi peserta didik secara optimal diperlukan strategi pembelajaran yang sistematis dan terarah, sementara itu strategi yang selama ini dipakai dalam pembelajaran kurang memberikan kebebasan pada peserta didik untuk mengembangkan berbagai kecerdasan baik intelektual, emosional, spiritual dan kreativitas.

Motivasi adalah perubahan energi dalam diri seseorang yang ditandai dengan munculnya feeling dan didahului dengan tanggapan terhadap adanya tujuan. Dalam belajar motivasi sangat dibutuhkan, hasil belajar akan optimal kalau ada motivasi (Sardiman, 2011: 73-74).

Hasil belajar merupakan hasil dari suatu interaksi tindak belajar dan tindak mengajar (Dimyati, 2013: 3). Hasil belajar dapat dikelompokkan menjadi tiga ranah yaitu kognitif, afektif, dan psikomotor yang secara eksplisit ke tiga ranah ini tidak dapat dipisahkan (Haryati, 2007: 22).: 26).

Berdasarkan observasi yang dilakukan peneliti, yaitu pada pembelajaran PAI di SMP Negeri 1 Lawang Wetan pada tgl 21 maret 2017, Setelah penulis berwawancara dengan ibu Nuraini, S.Pd.I selaku guru PAI SMP negeri 1 lawang wetan, penulis mendapati ada kesenjangan antara metode guru dan prestasi belajar peserta didik. Ada beberapa peserta didik yang prestasi belajarnya masih dibawah KKM, yaitu 7,0. Pada 
proses pembelajaran peserta didik masih ada yang susah diatur karena pikiran mereka sudah tidak di dalam kelas, peserta didik hanya mendengarkan penjelasan dari guru. Peserta didik kurang terlibat dalam proses pembelajaran. Meskipun metode pembelajaran guru yang digunakan selain ceramah menggunakan metode tanya jawab dan demonstrasi, tetapi guru masih dominan menggunakan metode ceramah dan belum juga menggunakan strategi pembelajaran yang banyak dikenalkan sekarang ini seperti dalam strategi pembelajaran PAIKEM.

Sementara ini asumsi peneliti bahwa penyebab hasil belajar peserta didik SMP Negeri 1 Lawang Wetan masih rendah adalah sebagai berikut:

1. Sistem pembelajaran banyak menekankan pada hafalan-hafalan, sehingga peserta didik cepat bosan dan mudah lupa.

2. Proses pembelajaran didominasi oleh guru, peserta didik hanya duduk, mendengarkan guru dan mengerjakan perintah guru.

3. Model pembelajaran kurang bervariasi, setiap peserta didik hanya diam, mendengarkan keterangan guru, bertanya (bila berani) dan mengerjakan soal yang ditugaskan oleh guru.

Melihat kondisi tersebut maka model pembelajaran guru harus dibenahi. Guru harus lebih bervariasi dalam menyampaikan informasi kepada peserta didik, sehingga peserta didik tertarik dan dapat terlibat dalam proses pembelajaran. Dengan terlibatnya peserta didik dalam proses pembelajaran akan merangsang peserta didik untuk mengikuti proses belajar tersebut. Sehingga akan cukup kuat untuk membuat kesan yang lama dan hidup dalam memahami pelajaran yang telah disampaikan, dan prestasi yang dihasilkan peserta didik akan lebih baik.Efektifitasmodel discovery learning pada pembelajaran Pendidikan Agama Islam diharapkan menjadi jawaban untuk merubah paradigma pendidikan dari teacher center menjadi student center.

Pola pikir yang mengagap bahwa guru sebagai satu-satunya sumber belajar harus segera ditinggalkan, karena lingkungan dan ilmu pengetahuan serta teknologi sebagai kunci pembuka sumber belajar yang sangat luas, Oleh karena itu kelas bukanlah satu-satunya tempat belajar bagi siswa. Belajar dilakukan dengan aktivitas aktif dimana anak melakukan banyak hal untuk mendapatkan pengalaman atau memperoleh informasi baru. Anak tidak lagi dianggap sebagai tokoh pasif yang hanya melakukan hal yang diperintahkan oleh pendidik, dimana anak tidak diberi kesempatan untuk menuangkan ide mereka, melakukan percobaan, dan berinteraksi dengan lingkungan.

Melihat kondisi itu penulis merasakan perlunya dilakukan penelitian Efektivitas Pembelajaran Pendidikan Agama Islam (PAI) Dengan Model Discovery Learning Dalam Meningkatkan Motivasi Dan Hasil Belajar Siswa di Kelas VIII SMP Negeri I Lawang Wetan Kecamatan Lawang Wetan dengan harapan yang ingin dicapai adalah minimal $75 \%$ dari jumlah siswa kelas VIII dapat mencapai indikator keberhasilan yang telah ditetapkan yaitu mencapai nilai minimal 75 . 


\section{Kajian Literatur}

Dimyati dan Mudjiono (1999: 87) mengemukakan tujuan pembelajaran menggunakan modeldiscovery learning adalah untuk meningkatkan keterlibatan peserta didik secara aktif dalam memperoleh dan memproses perolehan belajar, mengarahkan peserta didik sebagai pelajar seumur hidup, mengurangi ketergantungan kepada guru sebagai satu-satunya sumber informasi yang diperlukan peserta didik, dan melatih peserta didik untuk mengeksplorasi lingkungan sebagai sumber informasi.Metode discovery learning adalah pembelajaran yang berpusat pada peserta didik dengan menemukan sendiri ide dan konsep materi pembelajaran dengan guru hanya sebagai pengarah atau pembimbing pembelajaran. Metode discovery ini tergolong heuristik, karena peserta didik dibimbing untuk menemukan sendiri, jadi berbeda dengan kebiasaan ceramah untuk menerangkan keseluruhan materi kepada mereka.

Motivasi adalah keadaan dalam pribadi orang yang mendorong individu untuk melakukan aktivitas-aktivitas tertentu guna mencapai suatu tujuan (Sumandi, 2003: 70). Motivasi adalah kondisi fisiologis dan pisikologis yang terdapat dalam diri seorang yang mendorong untuk melakukan aktivitas tertentu guna mencapai suatu tujuan (kebutuhan).Hasil belajar merupakan hasil dari suatu interaksi tindak belajar dan tindak mengajar (Dimyati, 2013: 3). Hasil belajar dapat dikelompokkan menjadi tiga ranah yaitu kognitif, afektif, dan psikomotor yang secara eksplisit ke tiga ranah ini tidak dapat dipisahkan (Haryati, 2007: 22).

Jurnal yang ditulis Niluh Rahmawati jurusan Pendidikan Pancasila dan Kewarganegaraan fakultas Ilmu Sosial Universitas Pendidikan Ganesha tahun 2013 yang berjudul "Penerapan Model Pembelajaran Discovery Learning untuk Meningkatkan Hasil Belajar PKN Siswa" Penelitian ini bertujuan untuk meningkatkan hasil belajar PKn siswa kelas X4 SMA Negeri 1 Sukasada melalui penerapan model pembelajaran discovery learning. Penelitian ini adalah penelitian tindakan kelas. Pengumpulan data dalam penelitian ini dilakukan dengan metode observasi, wawancara, dan tes hasil belajar. Data yang diperoleh melalui metode observasi dan wawancara dianalisis dengan teknik deskriptif-kualitatif sedangkan data yang diperoleh melalui tes hasil belajar dianalisis dengan teknik deskriptif-kuantitatif. Kendala yang dihadapi dalam penerapan model discovery learning yaitu siswa belum terbiasa dengan penerapan model discovery learning sehingga sangat sulit bagi guru untuk mengeksplorasi respon-respon siswa. Solusi yang dilakukan adalah memberikan permasalahan di awal pertemuan supaya siswa membaca dan menemukan sendiri pemecahan masalah dalam buku atau sumber belajar yang dia miliki. Jurnal yang di tulis oleh Syahruddin Mimbar Universitas Pendidikan Ganesa "Pengaruh Model Pembelajaran Discovery Learning dan Minat Belajar Terhadap Hasil Belajar IPA Siswa" Penelitian ini bertujuan untuk mengetahui perbedaan hasil belajar IPA antara kelompok siswa yang mengikuti pembelajaran dengan menggunakan model discovery learning dengan model konvensional, dengan melibatkan minat belajar pada siswa kelas V Sekolah Dasar di Desa Bontihing, Kecamatan Kubutambahan pada tahun pelajaran $2013 / 2014$. 
Jurnal Pigur yang di tulis oleh Muhammad Aden, Universitas Riau Pekanbaru "Pengaruh Model Pembelajaran Discovery Learning Terhadap Aktivitas Belajar Siswa Mata Pelajaran Matematika" Penelitian ini bertujuan untuk mengetahui perbedaan hasil belajar siswa mata pelajaran matematika antara kelompok siswa yang mengikuti pembelajaran dengan menggunakan model discovery learning dengan model konvensional, dengan melibatkan aktivitas belajar tahun pelajaran 2014/2015.

Jurnal Edudikara yang di tulis oleh Maria Ulfah, Universitas Surakarta "Pengaruh Implementasi Model Pembelajaran Discovery Learning Terhadap Self Efficacydan Hasil Belajar Siswa Mata Pelajaran PAI" Penelitian ini bertujuan untuk mengetahui pengaruh self efficacy dan hasil belajar siswa mata pelajaran PAI siswa yang mengikuti pembelajaran dengan menggunakan model discovery learning. Berdasarkan hasil analisis data diperoleh: Ada pengaruh implementasi model pembelajaran discovery learning terhadap self efficacydan hasil belajar siswa mata pelajaran PAI sebesar $85 \%$.

\section{Metodologi Penelitian}

Jenis penelitian ini adalah penelitian lapangan (field research) yang berbentuk eksperimen, yang mana penelitian eksperimen itu sendiri adalah untuk menyelidiki kemungkinan saling hubungan sebab-akibat dengan cara mengenakan perlakuan (treatment) (Sugiyono, 2011:107). Penelitian ini merupakan penelitian dengan pendekatan kuantitatif, yang mana penelitian kuantitatif itu sendiri merupakan analisis menggunakan ukuran-ukuran frekuensi simbol atau atribut, atau menggunakan bilangan (numerik) agar mengandung makna yang lebih tepat daripada menggunakan kata-kata lebih, kurang, lebih kurang, bertambah, berkurang, dan lain-lain. Dari segi pendekatan, penelitian ini adalah penelitian eksperimen. Penelitian eksperimen ini dirancang dengan melakukan desain kelompok eksperimen yang dipilih secara random yaitu prates-pasca tes beracak (Nana, 2010:207): Dalam desain ini terdapat dua kelompok yang masingmasing dipilih secara random. Kelompok pertama diberi perlakuan (X) dan kelompok lain tidak. Kelompok yang diberi perlakuan disebut kelompok eksperimen dan kelompok yang tidak diberi perlakuan disebut kelompok kontrol. Pengaruh adanya perlakuan (treatment) adalah (O1:02). Dalam penelitian yang sesungguhnya pengaruh treatment dianalisis dengan uji beda, pakai statistik t-test.

\section{Hasil dan Diskusi}

Proses dan Pelaksanaan Pembelajaran Pendidikan Agama Islam dengan Model Discovery Learning di Kelas VIII SMP Negeri 1 Lawang Wetan Kecamatan Lawang Wetan

\section{Pembelajaran di Kelas Eksperimen}

Proses dan pelaksanaan pembelajaran PAI dengan model discovery learning di kelas VIII SMP Negeri 1 Lawang Wetan Kecamatan Lawang Wetan. Penerapan yang dilakukan guru Pendidikan Agama Islam untuk meningkatkan motivasi dan hasil belajar siswa. Penilaian tersebut dapat dilihat dari penilaian sikap, pengetahuan dan keterampilan.Adapun proses dan pelaksanaan pembelajaran Pendidikan Agama I slam 
dengan model discovery learning di kelas VIII SMP Negeri 1 Lawang Wetan Kecamatan Lawang Wetan yang dilakukan guru Pendidikan Agama Islam.

Pertemuan pada kelas eksperimen dilaksanakan pada hari kamis, 23 okteber 2017 pada kelas eksperimen pelaksanaan pembelajaran dilakukan dengan menggunakan modeldiscovery learning.

Pelaksanan pembelajaran Pendidikan Agama Islam dengan menggunakan model discovery learning dilaksanakan melalui tiga tahap, yaitu perencanaan, pelaksanaan dan evaluasi. Hal ini menunjukan pelaksanaan pembelajaran Pendidikan Agama Islam dengan menggunakan model discovery learning ini efektif dari proses dan hasil pembelajaran. Dari proses yaitu: a) meningkatnya antusias siswa, b) meningkatnya kemampuan siswa dalam memecahkan masalah.

\section{Uji Prasyarat Analisis}

Dari tabel di atas diperoleh data motivasi belajar kelas eksperimen untuk sampel nilai signifikansi P-value $=592>0,05$, dan motivasi belajar kelas kontrol untuk sampel nilai signifikansi $\mathrm{P}$-value $=261>0,05$ sehingga $\mathrm{p}$-value $>\alpha$. Dengan demikian sampel berasal dari sampel yang berdistribusi normal.

\section{Hasil Uji Homogenitas Motivasi Belajar Siswa}

Dari hasil tabel dapat diperoleh data motivasi belajar kedua kelas yang menjadi sampel nilai signifikansi $\mathrm{p}$-value $=\mathbf{2 3 5}>0,05$ sehingga $\mathrm{p}$-value $>\alpha$, dengan demikian sampel berasal dari populasi yang berdistribusi homogen. Berikut hasil uji normalitas dan homogenitas hasil belajar siswa yang dilakukan pada jumlah sampel yang ada, adapun jumlah sampel yang ada adalah berjumlah 70 orang yang terdiri dari 35 orang siswa untuk kelas eksperimen, dan 35 orang siswa untuk kelas kontrol. Sesuai ketentuan jika jumlah sampel genap maka uji yang digunakan adalah Kolmogorov Smirnov. Adapun uji normalitas dan homogenitas hasil belajar siswa dibantu SPSS 16, yaitu sebagai berikut:

a. Hasil Uji Normalitas Hasil Belajar Siswa

Dari hasil tabel diperoleh data hasil belajar kelas eksperimen untuk sampel nilai signifikansi P-value $=685>0,05$, dan hasil belajar kelas kontrol untuk sampel nilai signifikansi $\mathrm{P}$-value $=324>0,05$ sehingga $\mathrm{p}$-value $>\alpha$. Dengan demikian sampel berasal dari sampel yang berdistribusi normal.

b. Hasil Uji Homogenitas Hasil Belajar

Dari tabel di atas dapat diperoleh data motivasi belajar kedua kelas yang menjadi sampel nilai signifikansi $\mathrm{p}$-value $=\mathbf{3 6 7}>0,05$ sehingga $\mathrm{p}$-value $>\alpha$, dengan demikian sampel berasal dari populasi yang berdistribusi homogen.

\section{Hasil Angket Motivasi Belajar Siswa Kelas Eskperimen}

Berdasarkan hasil tabel diketahui bahwa siswa yang mendapatkan skor 100 sebanyak 7 orang, 99 sebangayk 1 orang, 98 sebanyak 2 orang, 96 sebanyak 1 orang, 95 sebanyak 3 orang, 92 sebanyak 2 orang, 91 sebanyak 1 orang, 90 sebanyak 9 orang, 89 sebanyak 1 orang, 88 sebanyak 1 orang, 86 sebanyak 1 orang, 85 sebanyak 3 orang, 82 sebanyak 1 orang, 80 sebanyak 1 orang, dan 75 sebanyak 1 orang. Selanjutnya setelah diketahui data skor motivasi belajar siswa kelas eksperimen, maka langkah 
berikutnya mencari mean variabel kelas eksperimen. Untuk mengetahui mean variable tersebut terlebih dahulu membuat tabel mean variabel I. Dari tabel diketahui jumlah $\mathrm{N}=$ 35, interval $=5, \boldsymbol{\Sigma} f x^{\prime}=19, \boldsymbol{\Sigma} f x^{\prime \mathbf{2}}=67$, dan M' adalah 88.Jadi interval skor motivasi belajar siswa pada mata pelajaran PAI dengan menggunakan model pembelajaran discovery learning yang tergolong tinggi/ baik adalah 97-100.

Skor yang tergolong rendah adalah 85-75. Dari tabel didistribusikan diperoleh gambaran mengenai motivasi belajar siswa pada mata pelajaran PAI dengan menggunakan model pembelajaran discovery learningyang tergolong rendah/kurang adalah sebanyak 6 orang siswa. Sedangkan skor yang tergolong sedang yaitu skor nilai dari 86 sampai dengan nilai 96. Dari tabel didistribusikan di atas diperoleh gambaran mengenai motivasi belajar siswa pada mata pelajaran PAI dengan menggunakan model pembelajaran discovery learningyang mendapat skor sedang sebanyak 19 orang siswa. Selanjutnya kita akan menentukan persentase skor kuesioner motivasi siswa kelas VIII.A SMP Negeri 1 Lawang Wetan Kecamatan Lawang Wetan, untuk lebih jelasnya dapat dilihat pada tabel berikut ini.

Berdasarkan tabel dapat diketahui bahwa motivasi belajar siswa pada mata pelajaran PAI dengan menggunakan model pembelajaran discovery learning kelas VIII.A SMP Negeri 1 Lawang Wetan Kecamatan Lawang Wetan skor tinggi dengan rentang nilai 97-100 sebanyak 10 orang atau 29\%, skor sedang dengan rentang nilai 8696 sebanyak 19 orang atau 54\%, dan skor rendah dengan rentang nilai 85-75 sebanyak 6 orang $17 \%$.

\section{Hasil Angket Motivasi Belajar Siswa Kelas Kontrol}

Untuk mengetahui skor motivasi belajar siswa pada mata pelajaran PAI dengan tidak menggunakan model pembelajaran discovery learning di SMP Negeri 1 Lawang Wetan Kecamatan Lawang Wetan, penulis telah melakukan penyebaran angket terhadap 35 orang siswa kelas VIII.B, angket diberikan untuk mengetahui motivasi belajar siswa pada kelas kontrol yang tidak melaksanakan model pembelajaran discovery learning, berdasarkan hasil angket didapatkan skor sebagai berikut:

Berdasarkan tabel diketahui bahwa siswa yang mendapatkan nilai 100 sebanyak 2 orang, 99 sebangayk 1 orang, 98 sebanyak 1 orang, 95 sebanyak 2 orang, 92 sebanyak 1 orang, 90 sebanyak 4 orang, 88 sebanyak 1 orang, 85 sebanyak 9 orang, 82 sebanyak 1 orang, 81 sebanyak 1 orang, 80 sebanyak 6 orang, 78 sebanyak 1 orang, 75 sebanyak 2 orang, 72 sebanyak 1 orang, dan 71 sebanyak 1 orang. Selanjutnya setelah diketahui data skor motivasi belajar siswa kelas kontrol, maka langkah berikutnya mencari mean variabel kelas kontrol. Untuk mengetahui mean variabel tersebut terlebih dahulu membuat tabel mean variabel II.

Dari tabel diketahui jumlah $\mathrm{N}=35$, interval $=5, \boldsymbol{\Sigma} f x^{\prime}=1 \mathbf{1}, \boldsymbol{\Sigma} f x^{\prime \mathbf{2}}=85$, dan $\mathrm{M}^{\prime}$ adalah 83, kemudian dilanjutkan dengan mencari mean variabel Y (variabel II).

Selanjutnya menentukan kategori skor tinggi, sedang, rendah (TSR) dengan rumus

$$
\begin{aligned}
& \text { Tinggi }=\mathbf{M}_{2}+1 . \mathbf{S D}_{2} \quad \text { (ke atas) } \\
& =84,57+1.7,25
\end{aligned}
$$




$$
\begin{aligned}
& =84,57+7,25 \\
& =91,82 \\
& =92(\text { dibulatkan })
\end{aligned}
$$

Jadi interval skor motivasi belajar siswa pada mata pelajaran PAI dengan menggunakan model pembelajaran discovery learning yang tergolong tinggi/ baik adalah 92-100. Dari tabel didistribusikan di atas diperoleh gambaran mengenai motivasi belajar siswa pada mata pelajaran PAI dengan menggunakan model pembelajaran discovery learning yang tergolong tinggi/ baik adalah sebanyak 7 orang siswa.

$$
\begin{aligned}
& \text { Rendah }=\mathbf{M}_{\mathbf{2}}-1 . \mathbf{S D}_{\mathbf{2}} \quad \text { (ke bawah) } \\
& =84,57-1.7,25 \\
& =84,57-7,25 \\
& =77,32 \\
& =77 \text { (dibulatkan) }
\end{aligned}
$$

Skor yang tergolong rendah/kurang adalah 77-71. Dari tabel di distribusikan di atas diperoleh gambaran mengenai motivasi belajar siswa pada mata pelajaran PAI dengan tidak menggunakan model pembelajaran discovery learning yang tergolong rendah/kurang adalah sebanyak 4 orang siswa. Sedangkan skor yang tergolong sedang yaitu skor nilai dari 78 sampai dengan nilai 91. Dari tabel didistribusikan di atas diperoleh gambaran mengenai motivasi belajar siswa pada mata pelajaran PAI dengan tidak menggunakan model pembelajaran discovery learning yang mendapat skor sedang sebanyak 20 orang siswa.

Berdasarkan tabel dapat diketahui bahwa skor motivasi belajar siswa pada mata PAI pada kelas kontrol dengan tidak menggunakan model pembelajaran discovery learning, siswa yang mendapatkan skor tinggi dengan rentang nilai 92-100 sebanyak 7 orang $(20 \%)$, siswa yang mendapat skor sedang dengan rentang nilai 78-91 sebanyak 24 orang $(68 \%)$, dan siswa yang mendapatkan skor rendah dengan rentang nilai 77-75 ada 4 orang $(12 \%)$.

\section{Perbedaan Motivasi Belajar Kelas Eksperimen Dengan Motivasi Belajar Kelas Kontro}

Untuk mengetahui perbedaan antara motivasi belajar kelas eksperimen dan motivasi belajar kelas kontrol, dalam hal ini menggunakan rumus uji-t, langkah selanjutnya setelah selesai mencari mean dan deviasi standar, maka selanjutnya mencari standard error perbedaan mean variabel I dan variabel II, dengan rumus sebagai berikut:

$$
\begin{aligned}
& =\sqrt{1,00^{2}-1,24^{2}} \\
& =\sqrt{1+1,537} \\
& =\sqrt{2,537} \\
& =1,592
\end{aligned}
$$

Dengan diperolehnya SE M1- M2 akhirnya dapat kita hitung $t_{\mathrm{o}}$ yaitu:

$$
=\frac{90,71-84,57}{1,592}
$$




$$
\begin{aligned}
& =\frac{6,14}{1,592} \\
& =3,856
\end{aligned}
$$

Langkah berikutnya memberikan interpretasi terhadap $t_{\mathrm{o}}$ :

$$
\begin{aligned}
& =(35+35)-2 \\
& =70-2 \\
& =68
\end{aligned}
$$

Dari penghitungan tersebut diketahui $\mathrm{t}_{\mathrm{o}}$ sebesar 3,856 sehingga dikonsultasikan dengan tabel "t" dengan df 68 baik pada tarap 5\% maupun pada tarap 1\%, ternyata bahwa pada tarap 5\% $\mathrm{t}_{\text {tabel }}$ atau $\mathrm{t}_{\mathrm{t}}=2,00$, pada tarap $1 \% \mathrm{t}$ tabel atau $\mathrm{t}_{\mathrm{t}}=2,65$, dengan perincian 2,00 $<3,856>2,65$. Dengan demikian hal ini mengandung makna bahwa motivasi belajar kelas eksperimen yang menerapkan model pembelajaran discovery learning lebih baik bila dibandingkan dengan motivasi belajar kelas kontrol yang tidak menerapkan model pembelajaran discovery learning.Dengan demikian karena t hitung ( $t_{0}$ ) lebih besar dari $t_{\text {tabel, maka }} \mathbf{H}_{\mathbf{o}}$ ditolak dan $\mathbf{H}_{\mathbf{a}}$ diterima, artinya terdapat perbedaan motivasi belajar Pendidikan Agama Islam sebelum dan sesudah menggunakan model discovery learning, dan dari perbandingan tersebut mengandung makna bahwa motivasi belajar kelas eksperimen lebih baik dari pada motivasi belajar kelas kontrol.

Perbedaan Hasil Belajar Siswa Pada Mata Pelajaran Pendidikan Agama Islam Antara Kelas yang Menggunakan Model Discovery Learning Dengan Kelas Kontrol Di Kelas VIII SMP Negeri 1 Lawang Wetan Kecamatan Lawang Wetan

\section{Hasil Belajar Kelas Kontrol}

Berdasarkan tabel diketahui bahwa siswa yang mendapatkan skor 15 sebanyak 3 orang, mendapatkan skor 14 sebanyak 2 orang, mendapatkan skor 11 sebanyak 17 orang, mendapatkan skor 10 sebanyak 7 dan mendapatkan skor 9 sebanyak 6 orang. Selanjutnya setelah diketahui data skor hasil belajar siswa kelas eksperimen, maka langkah berikutnya mencari mean variabel kelas eksperimen. Untuk mengetahui mean variabel tersebut terlebih dahulu membuat tabel mean variabel I.

Dari tabel di atas diketahui jumlah $\mathrm{N}=35$, interval $=1, \sum \mathrm{Fx}^{1}=14, \sum \mathrm{Fx}^{2}=76$, dan $\mathrm{M}^{\prime}$ adalah 11,5, dengan diketahui data tersebut selanjutnya mencari mean variabel $\mathrm{X}$ (variabel 1) dengan rumus sebagai berikut:

$$
\begin{aligned}
& =11,5+1\left(\frac{14}{35}\right) \\
= & 12,5+0,4 \\
= & 12,9
\end{aligned}
$$

Kemudian dilanjutkan dengan mencari deviasi standar variabel $X$ (Variabel 1) dengan dengan rumus sebagai berikut:

$$
\begin{aligned}
& =1 \sqrt{\frac{14}{35}-\left(\frac{14}{35}\right)^{2}} \\
& =1 \sqrt{0,4-(0,4)^{2}} \\
=1 & \sqrt{0,4-0,16}
\end{aligned}
$$




$$
\begin{aligned}
& =1 \sqrt{0,24} \\
& =1 \times 0,49 \\
& =0,49
\end{aligned}
$$

Selanjutnya menentukan kategori skor tinggi, sedang, rendah (TSR) dengan rumus:

$$
\begin{aligned}
& \text { Tinggi }=\mathbf{M}_{\mathbf{1}}+1 . \mathbf{S D}_{\mathbf{1}} \quad \text { (ke atas) } \\
& =12,9+1 \cdot 0,49 \\
& =12,9+0,49 \\
& =13,39 \\
& =13 \text { (dibulatkan) }
\end{aligned}
$$

Jadi interval skor hasil belajar siswa pada mata pelajaran PAI dengan menggunakan model pembelajaran discovery learning yang tergolong tinggi/ baik adalah 14-15. Dari tabel didistribusikan di atas diperoleh gambaran mengenai hasil belajar siswa pada mata pelajaran PAI dengan menggunakan model pembelajaran discovery learningyang tergolong tinggi/baik adalah sebanyak 5 orang siswa.

$$
\begin{aligned}
& \text { Rendah }=\mathbf{M}_{\mathbf{1}}-1 . \mathbf{S D}_{\mathbf{1}} \quad \text { (ke bawah) } \\
& =12,9-1.0,49 \\
& =12,9-0,49 \\
& =12,41 \\
& =12 \text { (dibulatkan) }
\end{aligned}
$$

Skor yang tergolong rendah adalah 11-10. Dari tabel didistribusikan di atas diperoleh gambaran mengenai hasil belajar siswa pada mata pelajaran PAI dengan menggunakan model pembelajaran discovery learningyang tergolong rendah/kurang adalah sebanyak 31 orang siswa. Sedangkan skor yang tergolong sedang yaitu skor nilai dari 12 sampai 13. Dari tabel didistribusikan di atas diperoleh gambaran mengenai hasil belajar siswa pada mata pelajaran PAI dengan menggunakan model pembelajaran discovery learningyang mendapat skor sedang tidak ada satu orang siswa. Selanjutnya kita akan menentukan persentase skor kuesioner hasil siswa kelas VIII.A SMP Negeri 1 Lawang Wetan Kecamatan Lawang Wetan, untuk lebih jelasnya dapat dilihat pada tabel berikut ini

Berdasarkan tabel di atas dapat diketahui bahwa hasil belajar siswa pada mata pelajaran PAI dengan menggunakan model pembelajaran discovery learning kelas VIII.A SMP Negeri 1 Lawang Wetan Kecamatan Lawang Wetan skor tinggi dengan rentang nilai 14-15 sebanyak 5 orang atau 14\%, skor sedang dengan rentang nilai 12-13 sebanyak 0 orang atau $0 \%$, dan skor rendah dengan rentang nilai 11-10 sebanyak 30 orang atau $86 \%$.

\section{Hasil Belajar Kelas Eksperimen}

Berikut hasil belajar siswa kelas eksperimen (kelas VIII.A) pada mata pelajaran Pendidikan Agama Islam di SMP Negeri 1 Talang Wetan Kecamatan Talang Wetan.

Berdasarkan tabel diketahui bahwa siswa yang mendapatkan skor 16 sebanyak 5 orang, mendapatkan skor 15 sebanyak 10 orang, mendapatkan skor 14 sebanyak 6 
orang, mendapatkan skor 13 sebanyak 7, mendapatkan skor 12 sebanyak 3 orang dan mendapatkan skor 11 sebanyak 4 orang. Selanjutnya setelah diketahui data skor hasil belajar siswa kelas eksperimen, maka langkah berikutnya mencari mean variabel kelas eksperimen. Untuk mengetahui mean variabel

Dari tabel diketahui jumlah $\mathrm{N}=35$, interval $=1, \sum \mathrm{Fx}^{1}=22, \sum \mathrm{Fx}^{2}=274$, dan $\mathrm{M}^{\prime}$ adalah 13,5, dengan diketahui data tersebut selanjutnya mencari mean variabel $\mathrm{X}$ (variabel 1) dengan rumus sebagai berikut:

$$
\begin{aligned}
& \mathbf{M}_{\mathbf{1}}=\mathbf{M}^{t}+i\left(\frac{\sum f x^{\prime}}{\mathbf{N}_{\mathbf{1}}}\right) \\
& =13,5+1\left(\frac{22}{35}\right) \\
& =14,5+0,63 \\
& =15,13
\end{aligned}
$$

Kemudian dilanjutkan dengan mencari deviasi standar variabel $\mathrm{X}$ (Variabel 1) dengan dengan rumus sebagai berikut:

$$
\begin{aligned}
& =1 \sqrt{\frac{22}{35}-\left(\frac{22}{35}\right)^{2}} \\
& =1 \sqrt{0,63-(0,63)^{2}} \\
=1 & \sqrt{0,63-0,3969} \\
& =1 \sqrt{0,2331} \\
& =1 \times 0,483 \\
& =0,483
\end{aligned}
$$

Selanjutnya menentukan kategori skor tinggi, sedang, rendah (TSR) dengan rumus:

$$
\begin{aligned}
& \text { Tinggi }=\mathbf{M}_{\mathbf{1}}+1 \cdot \mathbf{S D}_{\mathbf{1}} \quad \text { (ke atas) } \\
& =15,13+1 \cdot 0,483 \\
& =15,13+0,483 \\
& =15,613 \\
& =17 \text { (dibulatkan) }
\end{aligned}
$$

Jadi interval skor hasil belajar siswa pada mata pelajaran PAI dengan menggunakan model pembelajaran discovery learning yang tergolong tinggi/ baik adalah 17-18. Dari tabel didistribusikan di atas diperoleh gambaran mengenai hasil belajar siswa pada mata pelajaran PAI dengan menggunakan model pembelajaran discovery learningyang tergolong tinggi/baik adalah tidak ada satu.

$$
\begin{aligned}
& \text { Rendah }=\mathbf{M}_{\mathbf{1}}-1 . \mathbf{S D}_{\mathbf{1}} \quad \text { (ke bawah) } \\
& =15,13-1.0,483 \\
& =15,13-0,483 \\
& =14,647 \\
& =15 \text { (dibulatkan) }
\end{aligned}
$$


Skor yang tergolong rendah adalah 14-10. Dari tabel didistribusikan di atas diperoleh gambaran mengenai hasil belajar siswa pada mata pelajaran PAI dengan menggunakan model pembelajaran discovery learningyang tergolong rendah/kurang adalah sebanyak 20 orang siswa. Sedangkan skor yang tergolong sedang yaitu skor nilai dari 15-16. Dari tabel didistribusikan di atas diperoleh gambaran mengenai hasil belajar siswa pada mata pelajaran PAI dengan menggunakan model pembelajaran discovery learningyang mendapat skor sedang tidak ada satu orang siswa. Selanjutnya kita akan menentukan persentase skor kuesioner hasil siswa kelas VIII.A SMP Negeri 1 Lawang Wetan Kecamatan Lawang Wetan,

Berdasarkan tabel di atas dapat diketahui bahwa hasil belajar siswa pada mata pelajaran PAI dengan menggunakan model pembelajaran discovery learning kelas VIII.A SMP Negeri 1 Lawang Wetan Kecamatan Lawang Wetan skor tinggi dengan rentang nilai 17-18 tidak ada atau 0\%, skor sedang dengan rentang nilai 15-16 sebanyak 15 orang atau $43 \%$, dan skor rendah dengan rentang nilai 10-14 sebanyak 20 orang atau $57 \%$.

\section{Perbedaan Hasil Belajar Kelas Kontrol dan Kelas Eksperimen}

Dari Tabel dapat diketahui bahwa $n=70$ sampel penelitian yang terdiri dari kelas VIII.A dan kelas VIII.B. Adapun nilai rata-rata siswa VIII.A mendapat nilai 9.1 dengan kuadrat nilai rata-rata S2 menjadi 82.81, sedangkan nilai rata-rata kelas VIII.B adalah 7,9 dengan kuadrat nilai rata-rata S2 menjadi 62.41. Memberikan interpretasi terhadap " $\mathrm{t}_{\mathrm{h}}$ " sebagai berikut yaitu: df atau $\mathrm{db}=\left(\mathrm{n}_{1}+\mathrm{n}_{2}-2\right)=(35+35)-2=68$. Dengan df sebesar 68, maka dikonsultasikan dengan tabel Nilai " $\mathrm{t}$ ". Ternyata dalam tabel tidak ditemukan df sebesar 68, karena itu dipergunakan df yang terdekat, yaitu df. 50. Dengan df sebesar 50 diperoleh $t_{\text {tabel }}$ sebagai berikut:

\section{Pada taraf signifikansi 5\%: $\mathrm{t}_{\mathrm{t}}=2.00$}

Pada taraf signifikansi $1 \%: \mathrm{t}_{\mathrm{t}}=2,65$

Bila sampel berkorelasi atau berpasangan, membandingkan sebelum dan sesudah treatment atau perlakuan, atau membandingkan kelompok kontrol dengan kelompok ekperimen, maka digunakan $t$-test sampel related.

$$
\begin{aligned}
\mathrm{t} & =\frac{320-278}{\sqrt{\frac{82,81+62.41}{70}-2.0 .272\left[\frac{9.1}{70}\right]\left[\frac{7.9}{70}\right]^{2}}} \\
\frac{\mathrm{t}}{=} & \sqrt{\frac{145.22}{70}-2.0 .272(0.13)(0.0484)} \\
\mathrm{t} & =\sqrt{\mathrm{t} .074-2.0 .272(0.13)(0.0484)} \\
\sqrt{2.074-0.544(0.13)(0.0484)} & 42
\end{aligned}
$$




$$
\begin{aligned}
& \mathrm{t}=\frac{42}{\sqrt{1.53 \times(0.13)(0.0484)}} \\
& \mathrm{t}=\sqrt{0.00962}=0.0981 \\
& \mathrm{t}=\frac{42}{0.0981}=428.13
\end{aligned}
$$

Karena "t" yang kita peroleh dalam perhitungan (yaitu th $=428.13$ ) adalah lebih besar dari pada tt (baik pada taraf signifikansi 5\% maupun pada taraf signifikansi 1\%), maka Hipotesa nihil ditolak. Berarti terdapat perbedaan yang signifikan hasil belajar siswa pada mata pelajaran Pendidikan Agama Islam antara kelas yang menggunakan model discovery learning dengan kelas kontrol di kelas VIII SMP NEGERI 1 Lawang Wetan Kecamatan Lawang Wetan. Terdapat perbedaan hasil belajar Pendidikan Agama Islam kelas eksperimen yang menerapkan model pembelajaran discovery learning lebih baik bila dibandingkan dengan hasil belajar belajar kelas kontrol yang tidak menerapkan model pembelajaran discovery learning.Ini mengandung makna, hasil belajar PAI dengan menggunakan model

Berdasarkan hasil penelitian yang telah dilakukan antara sebelum dan sesudah pelaksanaan model pembelajaran discovery learning, menunjukan hasil belajar yang signifikan, dimana rata-rata hasil belajar sesudah penerapan model pembelajaran discovery learning lebih besar dari nilai sebelumnya.

Berdasarkan hasil penelitian telah diperoleh perbedaan hasil belajar siswa kelas eksperimen dengan hasil belajar siswa kelas kontrol serta data tentang peningkatan hasil belajar siswa dengan model pembelajaran discovery learning. Implemenatasi model pembelajaran discovery learningdalam meningkatkan hasil belajar siswa. Hasil belajar kognitif diperoleh dari tes formatif yang dilaksanakan pada akhir pembelajaran, untuk mengetahui adanya peningkatan dilihat dari meningkatnya prosentase keberhasilan siswa dari observasi awal.

\section{Kesimpulan}

Proses dan pelaksanan pembelajaran Pendidikan Agama Islam dengan model discovery learning di kelas VIII SMP NEGERI 1 Lawang Wetan Kecamatan Lawang Wetan dilaksanakan melalui tiga tahap, yaitu perencanaan, pelaksanaan dan evaluasi. Dan dari ketiga tahapan itu semuanya berjalan dengan baik.Berdasarkan data motivasi belajar siswa diperoleh nilai rata-rata kelas eksperimen 90.71, sedangkan rata-rata nilai kelas kontrol 84.57. Adapun nilai uji $\mathrm{T}$ menunjukkan bahwa nilait ${ }_{0} 3,856$. Kemudian setelah itu dikonsultasikan dengan $\mathrm{t}_{\text {tabel }}$ bahwa pada tarap $5 \% \mathrm{t}$ tabel atau $\mathrm{t}_{\mathrm{t}}=2,00$, pada tarap $1 \% \mathrm{t}$ tabel atau $\mathrm{t}_{\mathrm{t}}=2,65$, dengan perincian 2,00<3,856>2,65.Karena signifikansi $<0,05(0,000<0,05)$, maka dapat disimpulkan bahwa Ho ditolak dan Ha diterima, yang artinya terdapat perbedaan motivasi belajar Pendidikan Agama Islam antara kelas eksperimen yang menerapkan model discovery learning dengan kelas kontrol. Perbandingan tersebut mengandung makna bahwa motivasi belajar siswa kelas eksperimen lebih baik daripada motivasi belajar siswa kelas kontrol.Berdasarkan data 
hasil belajar diperoleh nilai rata-rata kelas eksperimen 82.81 , sedangkan nilai rata-rata kelas kontrol 62.41. Terdapat perbedaan nilai hasil belajar Pendidikan Agama Islam sebelum dan sesudah menggunakan model discovery learning.

1. Metode pembelajaran dengan menggunakan metode discovery learning dapat memberikan perbedaan yang baik terhadap motivasi dan hasil belajar siswa, jadi hendaknya para guru menerapkannya dalam proes pemeblajaran di sekolah sebagai salah satu variasi dalam model ajar sebagai usaha untuk menbangun kualitas belajar mengajar.

2. Dengan diterapkan model discovery learning ini, diharapkan dapat memicu semangat dan antusias belajar para siswa, agar tujuan pembelajaran dapat tercapai dengan baik

3. Diharapkan penelitian ini dapat menjad acuan bagi penelitian lainnya, dan bermanfaat bagi para akademis juga pembaca umumnya . 


\section{Daftar Pustaka}

Ali, M. D. (2008). Pendidikan Agama Islam. Alumni:Bandung.

Arikunto, S. (2006). Metodologi Penelitian. PT. Raja Grafindo Persada:Jakarta.

Azizy (2009). Pendidikan Agama Islam. Alfabeta:Bandung.

Davis (2011). Pendidikan Agama Islam. Alfabeta:Bandung.

Djamarah, S. B. \& Aswan, Z. (2005).Strategi Belajar Mengajar. Cet ke III, Rineka Cipta: Jakarta.

Hadi, S. (1996). Metodologi Penelitian. PT. Raja Grafindo Persada: Jakarta.

Hamalik, O. (2009). Kurikulum Pembelajaran. PT. Raja Grafindo Persada: Jakarta.

Nashar, (2004). Pranan Motivasi dan Kemampuan Awal Dalam Kegiatan Pembelajran. Jakarta : Delia Press.

Sudjana, N. (2005), penilaian hasil proses belajar mengajar, PT. Remaja Rosdakarya: Bandung.

Thursan, H. (2009), Belajar Secara Efektif, Jakarta: Pustaka Pembangunan Swadaya Nusantara. 
